Specijalna edukacija i rehabilitacija

(Beograd), Vol. 11, br. 4. 565-583, 2012.

Miodrag STOKIĆ*1

Vanja NENADOVIĆ*

Sanja ĐOKOVIĆ\#

*Institute for Experimental Phonetics

and Speech Pathology, Belgrade

\#Univerzitet u Beogradu

Fakultet za specijalnu edukaciju i rehabilitaciju
UDK: 159.946.3.072-056.264 ;

159.942.072-056.264

ID: 195805452

Originalni naučni rad

doi: 10.5937/specedreh11-2746

\title{
SHORT-TERM VERBAL MEMORY AND PSYCHOPHYSIOLOGICAL RESPONSE TO EMOTION - RELATED WORDS IN CHILDREN WHO STUTTER ${ }^{2}$
}

Emotions play a significant role in fluency disorders. In this research we wanted to examine immediate and delayed verbal recall for auditory presented words that carry information about different emotional state (emotion-related words) and emotionally neutral words in children who stutter $(N=35)$ and their peers $(N=35)$. Using only word semantics, we wanted to eliminate emotional verbal expresion of words as a factor that can influence memory abillities. In addition, we also wanted to examine skin conductance measure as an indicator of autonomic nervous system arousal during short-term memory task for emotion-related and emotionally neutral words.

Parental questionnaire (Stuttering Intensity in Children Who Stutter in Positive and Negative Emotion-Related Everyday Situations) was given to parents of children who stutter in order to collect data regarding stuttering severity in emotionally arousing situations in everyday life. Differences between the experimental and the control group in global memory capacity are highest in immediate recall $(p=0,01)$ with the tendency for lowering statistical significance with prolongation of retention interval.

1 E-mail: stokic_m@yahoo.com

2 Project supported by the Serbian Ministry of Science (178027 and 32032) 
Specijalna edukacija i rehabilitacija (Beograd), Vol. 11, br. 4. 565-583, 2012.

According to the questionnaire results, children who stutter show a higher degree of stuttering in situations with positive emotional valence $(p<0.00)$. Skin conductance measurements showed higher autonomic nervous system arousal during perception and free recall of positive emotion-related words in children who stutter when compared to negative and emotionally neutral words. The results indicate higher emotional arousal to positive emotions in children who stutter $(p=0.02)$, leading to either less fluent speech or suppression of verbal short-term memory capacity.

Keywords: short-term verbal memory, emotion-related words, skin conductance, stuttering

\section{INTRODUCTION}

In the literature reviewed, there are many findings about the influence of emotionality on memory formation and retrieval, implying that emotional stimuli are better remembered when compared to emotionally neutral ones. Most of the studies were examining the influence of emotional stimuli on memory using sounds, autobiographical events, words, and pictures (Bradley \& Lang, 2000; Rubin \& Schulkind, 1997; Kensinger \& Corkin, 2003; Bradley et al., 1992; Kleinsmith \& Kaplan, 1963). Regarding the differences between long-term and short-term memory, some studies determined that emotionality has an impact only on long-term memory without direct influence on short-term memory. In these studies, short-term memory was constant and emotionality of stimuli was irrelevant to retrieval capacity (Kleinsmith \& Kaplan, 1963, 1964; Clark et al., 1983; Kleinsmith \& Kaplan, 1963). Only a few studies published results that are opposite to the ones mentioned above. Burke et al. (1992) and Christianson et al. (1997) found that emotional stimuli arebetter remembered with significantly higher retrieval in short time intervals as well. Their study emphasized the influence of emotional stimuli on retrieval in short-term memory tasks suggesting that emotionality of stimuli leads to better recall not only in long-term but also in shortterm recall. Bover et al. (1978) use the term "emotion" to determine an affective state that follows the process of memory formation and recall of remembered stimuli. If stressful conditions are present 

emotion - related words in children who stutter

during memory formation and recall (memory task in experimental design), they can induce psychophysiological state of arousal that has an impact on the observed ongoing memory processes (Baddeley, 1972). When studying the influence of emotionality stimulus on memory recall and developing an adequate experimental design, it is important to be able to distinguish emotion from all those factors that might influence the observed process. In addition, there are stimuli that are new or presented in a manner that activates and directs attention leading to better recall due to attention shifting, especially in children who are still developing attention (Nenadovic et al, 2011), but not due to direct influence of emotionality. It is important to find connections between memory and emotions and to find appropriate theoretical explanations. When studying these relations, research needs to involve both behavioral and psychophysiological background of stimulus perception, memory formation, and recall.

Three studies dealt with the influence of emotional words on memory recall with opposite findings. Doerksen et al. (2001) and Pesta et al. (2001) found better recall of emotional words when compared to words with neutral emotional connotation. Kleinsmith and Kaplan (1963) found that emotionally neutral words had better recall if they were in an emotional context during a memory task. Findings from reviewed literature emphasize facilitation of recall in memory tasks that use emotional stimuli. A theoretical explanation for the influence of emotional stimuli on recall can be found in different attention focus leading to perception reduction for those stimuli that are irrelevant(stronger stimuli are in the focus of attention) (Easterbrook, 1959; Christianson \& Loftus, 1987). Another theoretical explanation is based upon a physiological mechanism when the increase in arousal creates a specific codification leading to the increase in recall for those stimuli that are extremely strong (Yerkes \& Dodson, 1988). These conflicting results require further research on the relationship between short-term memory and emotional content. Better recall of emotional words is due to both emotional arousal and semantic cohesion between words. This phenomenon of semantic relatedness is the most criticized factor in experimental designs (Talmi \& Moscovitch, 2004, Stokic et al., 2011) because of stronger semantic connections between emotional words when compared to randomly selected emotionally neutral words. 
Specijalna edukacija i rehabilitacija (Beograd), Vol. 11, br. 4. 565-583, 2012.

The skin conductance response (electro-dermal response) reflects better electrical conductivity of the skin when an arousing stimulus (external or internal) is presented. Skin conductance (SC) manifests the emotional state. Emotional state is manifested in the sympathetic nervous system activation changes that can be measured by placing electrodes on the lower surface of second and fourth finger where palmar and plantar sweat glands are placed. When the sympathetic nervous system is activated, skin conductance increases due to activation of the sweat glands. These changes of sweat glands secretion are measured using electrodes and acquisition software. An explanation for the increase in sweat glands activity is in increased sympathetic nervous system response to arousing incoming stimulus. Arousal is overall activation. It is an important part of emotional response. By measuring arousal, emotion itself cannot be measured, but one component of it can (Van der Kolk, 1997).

Only a few studies have dealt with memory in children and adults who stutter (Anderson \& Conture, 2000; Hakim \& Ratner, 2004; Anderson et al., 2006; Bajaj, 2007; Stokic et al., 2009). For the assessment of short-term verbal memory in children who stutter, researchers used non-word repetition skills. Also, visually presented words and pictures that carry emotional information are widely used. However, differential effect of emotional material on memory, depending on the retention interval, is far from clear (Ferre, 2002). Emotions play a significant role in stuttering. Previous research by Djordjevic et al., (2009) showed that children who stutter have better verbal expression of emotional speech compaired to their peers who do not stutter. This research showed that emotional reactions, emotional regulation and general level of sensitivity of children who stutter (CWS) might be more subtle than the emotional world of children who do not stutter (CWNS). Djordjevic et al., (2009) pointed to this quality as a possible factor causing the onset of stuttering.

Our study consists of two parts. In the first part, we wanted to examine specific memory capacities of children who stutter, in other words, memorization of verbal material where the emotional quality is at the semantic level only. We wanted to examine whether an effect of emotional information on short-term memory of CWS existed, or whether cognitive functioning was inhibited or enhanced at a subtler 
level of semantics. It was expected that positive and negative emotion- related words would be better remembered than emotionally neutral words in both the experimental and the control group, based on already mentioned studies of retention of emotional stimuli. In addition, we wanted to examine whether there are differences in memorizing words with positive and negative emotional content in children who stutter. The second part consisted of examining direct levels of emotional arousal in CWS. This experimental condition was the same as in the previous test situation, (in the task of memorizing emotionrelated vs. emotionally neutral words). Our assumption was that CWS would have higher levels of arousal (higher skin conduct measures) for emotion-related vs. emotionally neutral words in a short-term memory task. We assumed that there would be differences in skin conduct measures between negative and positive emotion-related words. In this phase, a parental questionnaire was administered, aimed at examining the emotional valence of situations connected with more intense stuttering in everyday life. We wanted to examine whether a differential effect exists for positive and negative situations at the level of stuttering.

\section{METHOD}

\section{Experiment I}

\section{Participants}

In our research we examined 35 boys who stutter (experimental group) and 35 boys who do not stutter (control group). All participants were native speakers of the Serbian language. All participants that were bilingual were excluded. The groups were equal in gender, age, hearing status and language skills. All participants were male, righthanded. Mean age in months for the experimental group was 105.23 and for the control group was 107.7 ( $\mathrm{p}=0.5$, no statistical significance). All participants passed standard hearing screenning, using tonal liminar audiometry (tresholds under $15 \mathrm{~dB}$ ). Both groups had normal language skills with no history of language disorders. Both groups 
Specijalna edukacija i rehabilitacija (Beograd), Vol. 11, br. 4. 565-583, 2012.

were tested using the Stuttering Severity Instrument (Riley, 1994) to determine differences in speech fluency between the two groups $(\mathrm{p}<0.000)$. The participants' parents gave their written consent that their children can participate in the experiment. The study was performed in accordance with the ethical standards laid down in the Declaration of Helsinki.

\section{Materials}

We have created three word lists for the purpose of our research, each containing six different words. All words are frequently used in the Serbian language.

The first list contained negative emotion-related words, the second list contained positive emotion-related words, and the third list contained emotionally neutral words. All three word lists were ballanced in word length (negative emotion-related words: Mean 4.67 letters, SD 0.92; positive emotion-related words: Mean 5.33 letters, SD 1.03; neutral words: Mean 4.50 letters, SD 0.54), without statistical signifficance among word length in the three lists $(\mathrm{p}>0.3)$.

\section{Procedures}

Word lists were read by a male speaker and recorded on computer. The words were read with the same intensity and without emotional verbal expression. Focusing only on word semantics, we wanted to eliminate emotional verbal expresion of words (prosody) as a factor that can influence delayed word recall. Time interval between each word was 500 milliseconds and sound intensity was set to $55 \mathrm{~dB}$, stereo. The participants listened to each list separately (first, the word list with negative emotionrelated words; second, the list with positive emotion-related words and third, the list with neutral words). After each list, they had to repeat what they had remembered. After the immediate recall task, they had a simple cognitive task (a game $\mathrm{X}-\mathrm{O}$ with the examiner). The purpose of this cognitive task was to shift attention from the presented word list, without burdening the memory system. After the cognitive task (30 seconds), the participants had to recall what they had remembered. This was named delayed memory task 1 . This procedure was repeated for each word list. After finishing immediate and delayed memory task 1 for all 
three word lists, the participants were tested using the Stuttering Severity Instrument (Riley, 1994) (15 minutes). After that, the participants were asked to recall each word they remembered from all of the three lists. This was named delayed memory task 2 . Thus, we wanted to determine how many words they remembered in total and their preference for negative, positive, or neutral words in delayed memory.

\section{RESULTS}

In Table 1 we can see that the participants from the control group achieved better results in each memory task (immediate, delayed 1 and delayed $2 \mathrm{X}$ negative, positive, and neutral words; 3X3 MANOVA (MS 68.32; F 11.73; $p=0.001$ ). Student T-test showed a statistical difference in the immediate recall task between the experimental and the control group ( $\mathrm{t}=-2.64 ; \mathrm{SD}=2.45 ; p=0.01)$; delayed recall task $1(\mathrm{t}=-2.11 ; \mathrm{SD}=2.66 ; p=0.05)$; delayed recall task $2(\mathrm{t}=-2.07 ; \mathrm{SD}=1.70$; $p=0.05)$. Differences between the experimental and the control group in global memory capacity are the biggest in immediate recall task. The tendency for reducing significant differences between the experimental and the control group with prolongation of retention interval was found. In the delayed recall task 2, CWS had equal results with CWNS in memory capacity for negative emotion-related words.

Table 1 - Memory capacity for emotion-related and emotionally neutral words in immediate recall task, delayed recall task 1 , and delayed recall task 2

\begin{tabular}{cccccccccc}
\hline & \multicolumn{3}{c}{ Immediate recall task } & \multicolumn{3}{c}{ Delayed recall task 1 } & \multicolumn{3}{c}{ Delayed recall task 2 } \\
\cline { 2 - 11 } & Negative & Positive & Neutral & Negative & Positive & Neutral & Negative & Positive & Neutral \\
\hline E & 3.92 & 3.62 & 3.62 & 3.46 & 2.38 & 2.77 & 3.08 & 1.92 & 2.62 \\
\hline C & 4.54 & 4.31 & 4.85 & 3.77 & 3.23 & 3.31 & 3.08 & 2.62 & 3.31 \\
\hline SD & 0.44 & 0.49 & 0.87 & 0.22 & 0.6 & 0.38 & 0.00 & 0.49 & 0.49 \\
\hline
\end{tabular}

The obtained data had normal distribution, so Student's T-test was used. There are no differences between the experimental and the control group in memory capacity for negative emotion-related words in all three recall tasks: 2 X3 MANOVA (MS 1.85; F 1.15; $\mathrm{p}=0.3$ ) but the subjects from the control group achieved better results in each recall task for positive emotion-related words (2X3 MANOVA: MS 10.78; F $9.80 ; p=0.002)$. The highest statistical significance is in delayed recall 
task 1 . The participants from the control group achieved better results in each recall task for emotionally neutral words (2X3 MANOVA: MS 11.54; F 6.78; $\mathrm{p}=0.01$ ) with the biggest differences in immediate recall task and delayed recall task 1 . The participants from the experimental group had better recall of negative emotion-related words in each recall task, but with significant differences in delayed 1 and delayed 2 recall tasks (3X3 MANOVA - negative, positive, neutral X immediate, delayed 1, delayed 2: MS 7.04; F 5.40; $p=0.01$ ). In addition, we can see that there are no differences among recall tasks and stimuli type in the control group (3X3 MANOVA - negative, positive, neutral X immediate, delayed 1, delayed 2: MS 2.34; F 1.47; $\mathrm{p}=0.2$ ).

\section{Experiment II}

\section{Objective}

Following the specific results in Experiment I, we wanted to further examine the negative effect of memorizing positive emotion related words in our experimental sample. Our further examination consisted of examining the psychophysiological level of arousal in CWS when exposed to a short-term memory task of negative, positive, and emotionally neutral words. Based on our previous findings, we expected a difference in the psychophysiological levels of arousal between emotionally negative and positive words.

In addition, in this phase a parental questionnaire was administered, aimed at examining the emotional valence of situations connected with more intense stuttering in everyday life. We wanted to examine whether a differential effect could be found for positive and negative situations at the level of stuttering. The objective of this experiment was to measure skin conductance response during the short-term memory task for negative and positive emotion-related words and emotionally neutral words in children who stutter. A distinction must be made between emotional stimuli and words with emotional connotation, the latter being the focus of the current study. The words that were used in the current study have a valence and an arousal rating that indicates an emotional connotation. In the following section, research 
examining the differences in skin conductance between words with emotional connotations will be presented.

\section{Participants}

The sample consisted of the same participants - experimental group, as in Experiment I.

\section{Materials}

We used the same list of words used in Experiment I. The parental questionnaire consisted of two lists, each containing five emotionrelated situations. The first list contained five situations with negative emotional valence and the second contained five situations with positive emotional valence. The parents were asked to scale each situation according to stuttering severity. The scale ranged from 0 to 5 ( 0 - no stuttering at all; 1 - stuttering is minimal, very rare, noticed only by parents; 2 - mild, present sometimes, noticed by everybody; 3 - moderate, almost always present, not intense, noticed by everybody; 4 - intense, always present with severe blockages but without severe reaction to stuttering; 5 - severe, always present with severe blockages, child gives up speaking, sweating, facial flushing, uncontrolled movements of lips and jaw are present).

\section{Procedures}

The participants were seated in a comfortable position in a quiet room. Two electrodes for skin conductance (SC) measurement (Biofeedback - ProComp 2, Thought Technology) were placed on the lower surface of second and fourth finger of the subdominant hand. Resting period was measured first ( 1 minute). Then the participants listened to word lists (negative and positive emotion-related words and emotionally neutral words) each containing six words, and after 10 seconds of retention interval, they had to recall words from each list consecutively. Average amplitude of skin conductance was recorded (resting state, period of listening and remembering, and recall), and analyzed offline. At the same time, their parents completed a questionnaire in another room. 
Specijalna edukacija i rehabilitacija (Beograd), Vol. 11, br. 4. 565-583, 2012.

Results of the Skin conductance measurements

Table 2 - Average SC response to negative and positive emotion-related words vs. resting state in short-term memory task

\begin{tabular}{cccccccc}
\hline & Resting & \multicolumn{3}{c}{ Listening \& remembering } & \multicolumn{3}{c}{ Recall } \\
\cline { 3 - 8 } & state & Negative & Positive & Neutral & Negative & Positive & Neutral \\
\hline Mean & 5.46 & 7.68 & 9.31 & 6.39 & 8.60 & 9.75 & 6.95 \\
\hline SD & 2.21 & 4.05 & 3.40 & 2.66 & 4.49 & 3.35 & 2.99 \\
\hline
\end{tabular}

Table 2 shows the amplitude value (mean and standard deviations) of SC for three experimental periods: resting state (beginning), listening and remembering emotion-related and emotionally neutral words and recall at the end of the experiment. We can see that minimal amplitude value of SC is during resting period (beginning of the experiment). During the period of listening and remembering negative, positive, and emotionally neutral words, there is an increase in SC value. The obtained data had normal distribution, so Student's T-test was used. The highest SC value is for positive emotion-related words $(t=-2.68, p=0.02)$. No significant differences were found in comparing resting state with listening and remembering negative emotion-related words and emotionally neutral words. During the period of listening and remembering negative, positive and emotionally neutral words the highest SC value was for positive emotion - related words, then for negative emotion - related words. The lowest SC value was for emotionally neutral words.

Similar results were obtained during recall period. Generally, SC value during recall of all three word categories was higher when compared to period of listening and remembering, but without statistically significant differences. When compared to resting state, statistically significant difference $(t=-3.02, p=0.001)$ was obtained during recall period of positive emotion-related words. During recall period of negative, positive and emotionally neutral words, the highest $S C$ value was for positive emotion - related words, then for negative emotion related words. The lowest SC value was for emotionally neutral words (the same order as during the period of listening and remembering). 


\section{Parental questionnaire}

Following experiment II and in the light of testing the hypothesis on the effect of positive emotionally valenced stimuli, we have designed a questionnaire consisting of a list of everyday situations with positive or negative emotional valence. Parents of CWS filled out the questionnaire. Results from the questionnaire are given in Table 3.

Table 3 - Parental questionnaire results (Stuttering intensity in children who stutter in positive and negative emotion-related everyday situations)

\begin{tabular}{lcclcc}
\hline \multicolumn{3}{c}{ Positive situations } & \multicolumn{4}{c}{ Negative situations } \\
\hline Item & $\mathrm{M}$ & $\mathrm{SD}$ & Item & $\mathrm{M}$ & $\mathrm{SD}$ \\
$\begin{array}{l}\text { Visit of a dear } \\
\text { family member/ } \\
\text { friend }\end{array}$ & 3.25 & 1.67 & $\begin{array}{l}\text { Conflict with } \\
\text { member of the } \\
\text { family/friend }\end{array}$ & 2.25 & 1.28 \\
$\begin{array}{l}\text { Birthday } \\
\text { celebration }\end{array}$ & 3.88 & 1.25 & $\begin{array}{l}\text { Illness/ } \\
\text { hospitalization }\end{array}$ & 2.38 & 0.92 \\
\hline $\begin{array}{l}\text { Planned trip/ } \\
\text { vacation }\end{array}$ & 2.38 & 1.19 & $\begin{array}{l}\text { Unplanned trip } \\
\text { /moving }\end{array}$ & 1.38 & 1.3 \\
$\begin{array}{l}\text { School/sports } \\
\text { success }\end{array}$ & 3.38 & 1.6 & $\begin{array}{l}\text { Failure in } \\
\text { school/sports }\end{array}$ & 2.38 & 1.68 \\
\hline $\begin{array}{l}\text { Pleasant } \\
\text { surprise }\end{array}$ & 3.75 & 1.39 & $\begin{array}{l}\text { Unpleasant } \\
\text { surprise }\end{array}$ & 2.88 & 1.25 \\
\hline
\end{tabular}

The Obtained data had normal distribution, so Student's T-test was used. The paired samples test revealed $t(37)=3.95, p<0.00$. A statistically significant difference was found between situations with positive and negative emotional valence. These results are in concordance with our hypothesis that a differential effect existed between positive and negative situations. According to the questionnaire results, CWS show a higher degree of stuttering in situations with positive emotional valence. Among these situations, birthday celebration and pleasant surprise were situations marked with the highest scores by parents, when the amount of stuttering was considered. Our results are also in accordance with the results from skin conductance measurements, where psychophysiological parameters were tested.

We have not come across similar findings in this area of research in recent literature review and therefore, these results require special consideration. Replications or similar findings could possibly raise new questions in interpreting everyday activities as triggers for stuttering. 
Specijalna edukacija i rehabilitacija (Beograd), Vol. 11, br. 4. 565-583, 2012.

\section{DISCUSSION}

First, we wanted to show whether children who stutter (CWS) have equal memory capacity in general, when compared to their peers who do not stutter. However, this study showed the opposite. Children who do not stutter showed better results in each memory task. Second, we wanted to examine preference for either emotion-related or emotionally neutral words in both groups. We found that children who stutter have significantly different achievement in memory tasks when we used different stimuli type. CWS had significantly better results in the memory task that included negative emotion-related words as stimuli when compared to positive emotion-related and emotionally neutral words. Children who do not stutter had equal results in memory tasks that included different stimuli type. In recent literature review, experimental results indicate that when compared to their peers who do not stutter, CWS were more reactive and less able to regulate their emotions (Karrass et al, 2006). In addition, they had poorer regulation of directed attention. Emotional reactivity and regulation influence the development of communication (Dixon and Smith, 2000). With regard to these findings, there is a reason to establish a correlation between emotional reactivity and regulation and stuttering. This statement is in accordance with recent literature reviews regarding emotional development of children who stutter (Anderson et al., 2003; Guitar, 1998), and adults who stutter (Alm, 2004). Embrechts et al. (1998) linked specific features of emotional reactivity to stuttering in children. Initial inhibition can explain the tendency for reducing the differences between the experimental and the control group in memory task achievement with prolongation of retention interval (CWS are inhibited when they have to do a verbal task immediately). Stocker and Parker (1977) found a relationship between recall and stuttering in children. They found that increased fluency allowed children to use previously suppressed linguistic data. A possible explanation for negative emotion- related words preference in memory tasks in children who stutter (CWS) might be in the relation to greater emotional reactivity to positive emotions. We partially confirmed this statement in Experiment II where CWS showed higher autonomic nervous system arousal during perception 

emotion - related words in children who stutter

and free recall of positive emotion-related words. Emotional reactivity refers to the tendency to experience frequent and intense emotional arousal. Spinrad et al., (2004) found important individual differences in reactivity to positive emotions as well. Ahadi and Rothbart (1994) define the term "emotional regulation" as modulation of internal emotional reactivity regardless of whether it has positive or negative valence. These authors state that attention regulation involves ability to shift attention away from something that is emotionally arousing. In that manner, emotional effects of the stimulus are reduced.

Our findings suggest that relatively greater emotional reactivity (especially for positive emotions) experienced by children who stutter may contribute to better recall for negative emotion-related words in our memory tasks. This study showed that CWS are more reactive to positive emotions in memory tasks (positive emotion-related words referring to word semantics). Greater emotional reactivity leads to more intense stuttering so a compensatory mechanism could be involved in attention shifting towards those stimuli that are less emotional. In that way, stuttering is reduced, leading to speech that is more fluent. In addition, these results could lead to confirmation of the preverbal self - monitoring hypothesis as one of the possible causes of stuttering. Self-monitoring of speech plays a critical role in preventing speech errors, but some researchers have suggested that detecting and correcting errors in the preverbal speech plan leads to decreased fluency (Postma et al., 1990). This hypothesis combined with emotional reactivity to verbal stimuli could explain our results in Experiment I, indicating better memory capacity for negative emotion-related words. Further research in interference analysis of all stimuli type and preference for one of them when they are combined in one memory task, will provide us with more experimental data which will help us better understand memory system of children who stutter. Also, our future goal is to use results of our research to create novel approaches to treatment of children who stutter. 


\section{REFERENCES}

1. Ahadi, S.A. \& Rothbart, M.K. (1994). Temperament, development, and the Big Five. In: Kohnstamm (GA, Halverson CF Jr., editors). The developing structure of temperament and personality from infancy to adulthood (pp. 189-207). Hillsdale, NJ: Erlbaum.

2. Alm, P.A. (2004). Stuttering, emotions, and heart rate during anticipatory anxiety: A critical review. Journal of Fluency Disorders, 29, 123-133.

3. Anderson, J.D.,Wagovich, S.A. \& Hall, N.E. (2006). Nonword repetition skills in young children who do and do not stutter. Journal of Fluency Disorders, 31(3), 177-199.

4. Anderson, J.D. \& Conture, E. (2000). Language abilities of children who stutter: A preliminary study. Journal of Fluency Disorders, 25, 283-304.

5. Anderson, J.D., Pellowski, M.W., Conture, E.G. \& Kelly, E.M. (2003). Temperamental characteristics of young children who stutter. Journal of Speech, Language and Hearing Research, 46, 1221-1223.

6. Baddeley, A.D. (1972). Selective attention and performance in dangerous environments. British journal of psychology, 63 (4), 537-46.

7. Bajaj, A. (2007). Working memory involvement in stuttering: Exploring the evidence and research implications. Journal of Fluency Disorders, 32(3), 218-238.

8. Bower G.H., Monteiro K.P. \& Gilligan S.G. (1978). Emotional mood as a context for learning and recall. Journal of Verbal Learning and Verbal Behavior, 17, 573-585.

9. Bradley, M.M., Greenwald, M.K., Petry, M.C. \& Lang, P.J. (1992). Remembering pictures: pleasure and arousal in memory. Journal of Experimental Psychology, Learning, Memory, and Cognition, 18 (2), 379- 390.

10. Bradley, M.M. \& Lang, P.J. (2000). Affective reactions to acoustic stimuli. Psychophysiology, 37(2), 204-215.

11. Burke, A., Heuer, F. \& Reisberg, D. (1992). Remembering emotional events. Memory and Cognition, 20, 277-290.

12. Christianson, S. \& Loftus, E.F. (1987). Memory for traumatic events. Applied Cognitive Psychology, 1(4), 225-239.

13. Clark, M.S., Milberg, S. \& Ross, J. (1983). Arousal cues arousal related material in memory: Implications for understanding 
Stokić, M. i sar.: Short-term verbal memory and psychophysiological response to emotion - related words in children who stutter

effects of mood on memory. Journal of Verbal Learning and Verbal Behavior, 22, 633-649.

14. Doerksen, S. \& Shimamura, A.P. (2001). Source memory enhancement for emotional words. Emotion, 1(1), 5-11.

15. Dixon, W.E. \& Smith, P.H. (2000). Links between early temperament and language acquisition. Merrill-Palmer Quarterly, 46, 417-440.

16. Djordjevic, V., Stevovic, N., Stokic, M. \& Sovilj, M. (2009). Emotional verbal expression-diagnostic implication. Proceedings - Speech and Language 2009, 3rd International Conference on Fundamental and Applied Aspects of Speech and Language, Proceeding, ISBN 978-86-81879-26-9, str. 79 - 84.

17. Easterbrook, J.A. (1959). The effect of emotion on cue utilization and the organization of behavior. Psychological Review, 66(3), 183201. pmid:13658305. doi:10.1037/h0047707

18. Embrechts, M., Ebben, H., Franke, P. \& Van de Poel, C. (1998). Temperament: A comparison between children who stutter and children who do not stutter (In: Healey, E.C., \& Peters, H.F.M., editors). Stuttering: Proceedings of the second world congress on fluency disorders. Vol. 2. Nijmegen, The Netherlands: University Press Nijmegen

19. Ferre, P. (2002). Advantage for Emotional Words in Immediate and Delayed Memory Tasks: Could it be Explained in Terms of Processing Capacity? The Spanish Journal of Psychology, 5(2), 78-89.

20. Guitar, B. (1998). An integrated approach to its nature and treatment. Baltimore, MD: Williams \& Wilkens.

21. Hakim, H.B. \& Ratner, N.B. (2004). Nonword repetition abilities of children who stutter: an exploratory study. Journal of Fluency Disorders, 29(3), 179-199.

22. Karrass, J., Walden, T.A., Conture, E.G., Graham, C.G., Arnold, H.S., Hartfield, K.N. \& Schwenk, K.A. (2006). Relation of emotional reactivity and regulation to childhood stuttering. Journal of Communication Disorders, 39(6), 402-423.

23. Kensinger, E.A. \& Corkin, S. (2003). Memory enhancement for emotional words: Are emotional words more vividly remembered than neutral words? Memory and Cognition, 31, 1169- 1180.

24. Kleinsmith, L.J. \& Kaplan, S. (1963). Paired-associate learning as a function of arousal and interpolated interval. Journal of Experimental Psychology, 65(2), 190-3. pmid:14033436. doi:10.1037/h0040288

25. Nenadović, V., Đoković, S. \& Pečenica, D. (2011). Razvoj auditivne pažnje. Specijalna edukacija i rehabilitacija, 10 (1), 77-92. 
Specijalna edukacija i rehabilitacija (Beograd), Vol. 11, br. 4. 565-583, 2012.

26. Pesta, B.J., Murphy, M.D. \& Sanders, R.E. (2001). Are emotionally charged lures immune to false memory? Journal of Experimental Psychology, Learning, Memory, and Cognition, 27, 328-338.

27. Postma, A., Kolk, H. \& Povel, D. (1990). On the relation among speech errors, influences, and self repairs. Language and Speech, 33, 19-29.

28. Riley, G.D. (1994). Stuttering Severity Instrument for children and adults-3 (SSI-3). 3rd ed. Austin, TX: Pro-Ed.

29. Rubin, D. \& Schulkind, M., (1997). Distribution of important and word-cued autobiographical memories in 20, 35-, and 70-year-old adults. Psychology and Aging, 12, 524- 535.

30. Spinrad, T.L., Eisenberg, N., Harris, E., Hanish, L., Fabes, R.A., Kupanoff, K. et al. (2004). The relation of children's everyday nonsocial peer play behavior to their emotionality, regulation, and social functioning. Child Development, 40, 67-80.

31. Stocker, B. \& Parker, E. (1977). The relationship between auditory recall and dysfluency in young stutterers. Journal of Fluency Disorders, 2(3), 177-187.

32. Stokić M., Stevović N. \& Sovilj M. (2009). Verbalmemory at children who stutter and emotion-related word semantic. Proceedings - Speech and Language 2009, 3rd International Conference on Fundamental and Applied Aspects of Speech and Language, Proceeding, ISBN 978-86-81879-26-9, pp.134-140.

33. Stokić, M., Milosavljević, Z. \& Maksimović, S. (2011). Oscilatorna moždana dinamika tokom procesiranja reči. Specijalna edukacija $i$ rehabilitacija, 10, 1, str. 141-152

34. Talmi, D. \& Moscovitch, M. (2004). Can semantic relatedness explain the enhancement of memory for emotional words? Memory \& Cognition, 32 (5), 742-751.

35. Van der Kolk, B.A. (1997). The psychobiology of posttraumatic stress disorder. Journal of Clinical Psychiatry, 58, 16- 24

36. Yerkes, R.M. \& Dodson, J.D. (1988). The relation of strength of stimulus to rapidity of habit-formation. Journal of Comparative Neurology and Psychology, 18, 459-482. 


\title{
KRATKOROČNA VERBALNA MEMORIJA ZA REČI SA EMOCIONALNIM NABOJEM I PSIHOFIZIOLOŠKA REAKCIJA KOD DECE SA MUCANJEM
}

\author{
Miodrag Stokić*, Vanja Nenadović*, Sanja Đokovićn \\ *Institut za eksperimentalnu fonetiku i patologiju govora, \\ ${ }^{*}$ Univerzitet u Beogradu - Fakultet za specijalnu edukaciju i rehabilitaciju
}

\section{Rezime}

Emocije igraju značajnu ulogu u poremećajima fluentnosti govora. U ovom istraživanju želeli smo da ispitamo neposredno verbalno pamćenje za auditivno prezentovane reči koje nose informacije o različitim emocionalnim stanjima (emocionalno obojene reči) i emotivno neutralne reči kod dece koja mucaju. Oslanjajući se samo na semantiku reči, hteli smo da eliminišemo emocionalnu verbalnu ekspresiju reči kao faktor koji može da utiče na sposobnost upamćivanja. Osim toga, želeli smo ispitati meru provodljivosti kože kao pokazatelja aktivacije autonomnog nervnog sistema tokom ispitivanja kratkotrajne memorije za emocionalno negativne, pozitivne i emocionalno neutralne reči.

Upitnik za roditelje je primenjen u u cilju prikupljanja podataka o težini mucanja u emocionalno jakim situacijama u svakodnevnom životu. Razlike između eksperimentalne (dece koja mucaju) i kontrolne grupe u globalnom kapacitetu memorije su najviši izražene na zadatku neposredne reprodukcije zapamćenih reči s tendencijom smanjenja statističke značajnosti sa produženjem vremenskog intervala između izlaganja stimulusu i reprodukcije.

Prema rezultatima Upitnika, deca koja mucaju pokazuju veći stepen mucanja u situacijama s pozitivnim emocionalnim nabojem. Merenja provodljivosti kože pokazala su veću aktivaciju autonomnog nervnog sistema tokom percepcije i reprodukcije reči sa pozitivnim emocionalnim nabojem kod dece koja mucaju u poređenju sa rečima sa negativnim emocijama i neutralni rečima, što je dovelo do smanjenja fluentnosti ili supresije trenutnog kapaciteta verbalne memorije.

Ključne reči: Kratkoročno verbalno pamćenje, reči sa emocionalnim nabojem, psihofiziološka reakcija, mucanje 


\section{Appendix 1}

\section{Parental Questionnaire}

In front of you is a list of everyday situations with positive and negative emotional valence. Rate each situation on a scale of 0 to 5 according to your own estimation of your child's stuttering intensity. The scale should range as follows:

0 - no stuttering at all

1 - stuttering is minimal (present very rear, noticed only by parents)

2 - mild (present sometimes, noticed by everybody)

3 - moderate (almost always present, not intense, noticed by everybody)

4 - intense (always present with severe blockages but without sever reaction to stuttering)

5- severe (always present with severe blockages, child gives up speaking situation, present sweating, facial flushing, uncontrolled movements of lips and jaw)

\section{A. Emotionally negative situations:}

Conflict with member of

the family/friend

Illness, hospitalization

Unplanned trip or moving

Failure in school/sports

Sudden unpleasant situation

$\begin{array}{llllll}0 & 1 & 2 & 3 & 4 & 5 \\ 0 & 1 & 2 & 3 & 4 & 5 \\ 0 & 1 & 2 & 3 & 4 & 5 \\ 0 & 1 & 2 & 3 & 4 & 5 \\ 0 & 1 & 2 & 3 & 4 & 5\end{array}$

\section{B. Emotionally positive situations}

Visit of a dear family

member/friend

$\begin{array}{llllll}0 & 1 & 2 & 3 & 4 & 5 \\ 0 & 1 & 2 & 3 & 4 & 5 \\ 0 & 1 & 2 & 3 & 4 & 5 \\ 0 & 1 & 2 & 3 & 4 & 5 \\ 0 & 1 & 2 & 3 & 4 & 5\end{array}$


Stokić, M. i sar.: Short-term verbal memory and psychophysiological response to emotion - related words in children who stutter

\section{Appendix 2}

Word lists for Experiment I - SHORT-TERM VERBAL MEMORY AND THE PSYCHOPHYSIOLOGICAL RESPONSE TO EMOTION - RELATED WORDS IN CHILDREN WHO STUTTER

Participant number

Date of Birth

Date of Test
A. Negative Emotion-related words ILLNESS
FEAR
PAIN
DEATH
CRY
SADNESS
B. Positive Emotion-related words HAPPINESS
SMILE
LOVE
JOY
HEALTH
LOVE
C. Emotionally neutral words
FRUIT
BIRD
TOOL
PICTURE
DAYS
JEWERLY

Primljeno: 18.10.2012.
Auditory screening passed YES NO

Score on Glyndon Riley Test

Participants age in months
DELAYED 2

DELAYED 1

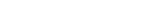

\section{IMMEDIATE RECALL DELAYED $1 \quad$ DELAYED 2}

\section{IMMEDIATE RECALL DELAYED $1 \quad$ DELAYED 2}

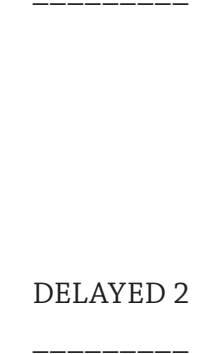

Prihvaćeno: 6.12.2012. 